\title{
Sideroxylon mascatense: A New Crop for High Elevation Arid Climates
}

\author{
Eric Hopkins*, Rashid Al-Yahyai
}

$$
\text { البوت (Sideroxylon mascatense) محصول جديد للمناطق المرتفعة ذات المناخ الجافيك هوبكنز و راشد اليحيائي البكاف }
$$

ABSTRACT. This paper reviews the existing research on Sideroxylon mascatense, and provides an argument for being considered a fruit crop in cultivated production systems in the Sultanate of Oman and elsewhere. Climate change due to global warming has adverse effects on the agro-ecosystems of mountain regions in marginal climate zones. For example, in the Western Hajar Mountains of Oman, yields of the temperate fruit crops have decreased in recent years as temperature and other climate anomalies have increased. Other fruit-bearing wild plants have also been impacted by extreme weather fluctuations, particularly those that occupy a narrow altitudinal range. One such plant is S. mascatense, a currently underutilized fruiting plant found growing in the wild all through the Middle East and other arid mountainous regions. Two fruiting types of S. mascatense are found in Oman, both of which are seasonally wild harvested by mountain inhabitants and sold in markets as well as along the roadsides. While some specimens exist in cultivated areas, propagation and new plantings are non-existent. Regeneration in the wild is also in decline in Oman, possibly due to climate change. Increasing S. mascatense populations could be achieved via propagation, as well as commercial cultivation, although further research is needed into cropping systems and best practice methods.

KEYWORDS: Oman; Mountains; Oasis Agriculture; Agroforestry; Climate Change; Native Plants.

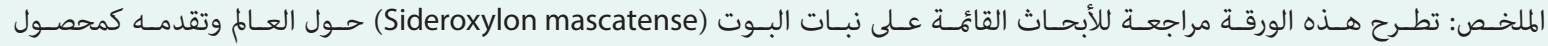

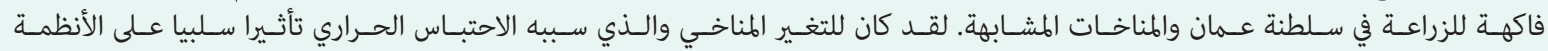

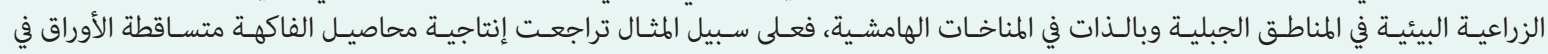

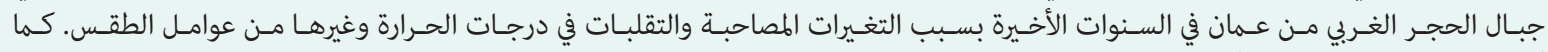

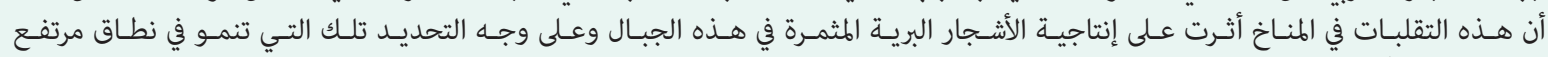

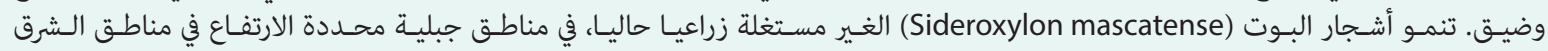

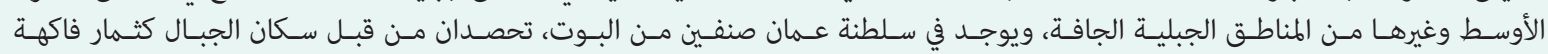

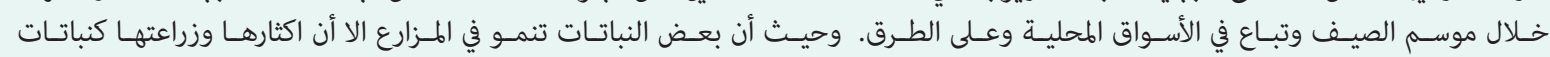

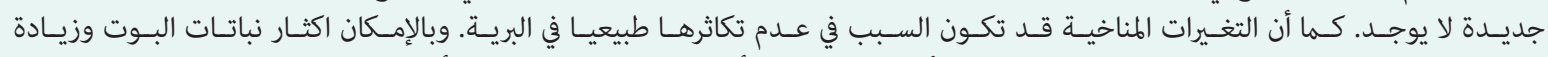

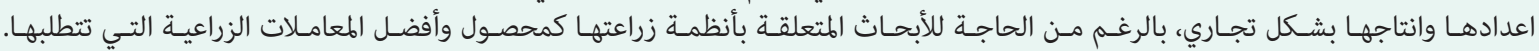

$$
\text { الكلمات المفتاحية: عمان، الجبال، زراعة الواحات، الحراجة الزراعية، التغير المناخي، النباتات المحلية }
$$

\section{Introduction}

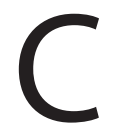
limate change, such as global warming, affects agriculture to varying degrees throughout the world. Rising temperatures, frequently occurring extreme storm events, drought, and booming populations have taken their toll on food security and the economies of many nations. To help counteract the negative effects of climate change, scientists have employed various strategies from climate modelling to plant breeding (El Chami and Daccache, 2015; Dubey et al., 2017). A key strategy to cope with climate change is agricultural system adaptation (Howden et al., 2007). As temperatures and weather patterns change on the local level, so the systems, methods, and crops should be utilized in local agriculture.

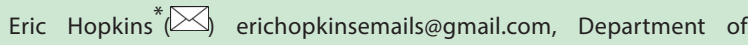
Crop Sciences, College of Agricultural and Marine Sciences, Sultan Qaboos University, P. O. Box 34-123, Oman.
Traditional agriculture in Oman is based around oases which are irrigated through channels of the Falaj network fed by mountain springs (Zekri et al., 2011). Oasis agriculture is a system of agroforestry which relies on perennial fruiting crops with medium to high canopies providing shade to forage crops and vegetables growing close to the ground (Atangana et al., 2014; Hopkins and Al-Yahyai, 2015). Oases are found throughout Oman from the plains to the mountains (Luedeling and Buerkert, 2008a).

Climate change due to global warming has changed the agrarian and wild landscapes in the Western Hajar Mountains of Oman, as it has in other mountain regions in marginal climate zones. For example, wild native species like Juniperus seravschanica have been affected by climate change (MacLaren, 2016). As explained by Al-Farsi et al. (2017), at lower elevations J. seravschanica have foliage dieback, recruitment is limited, and even 


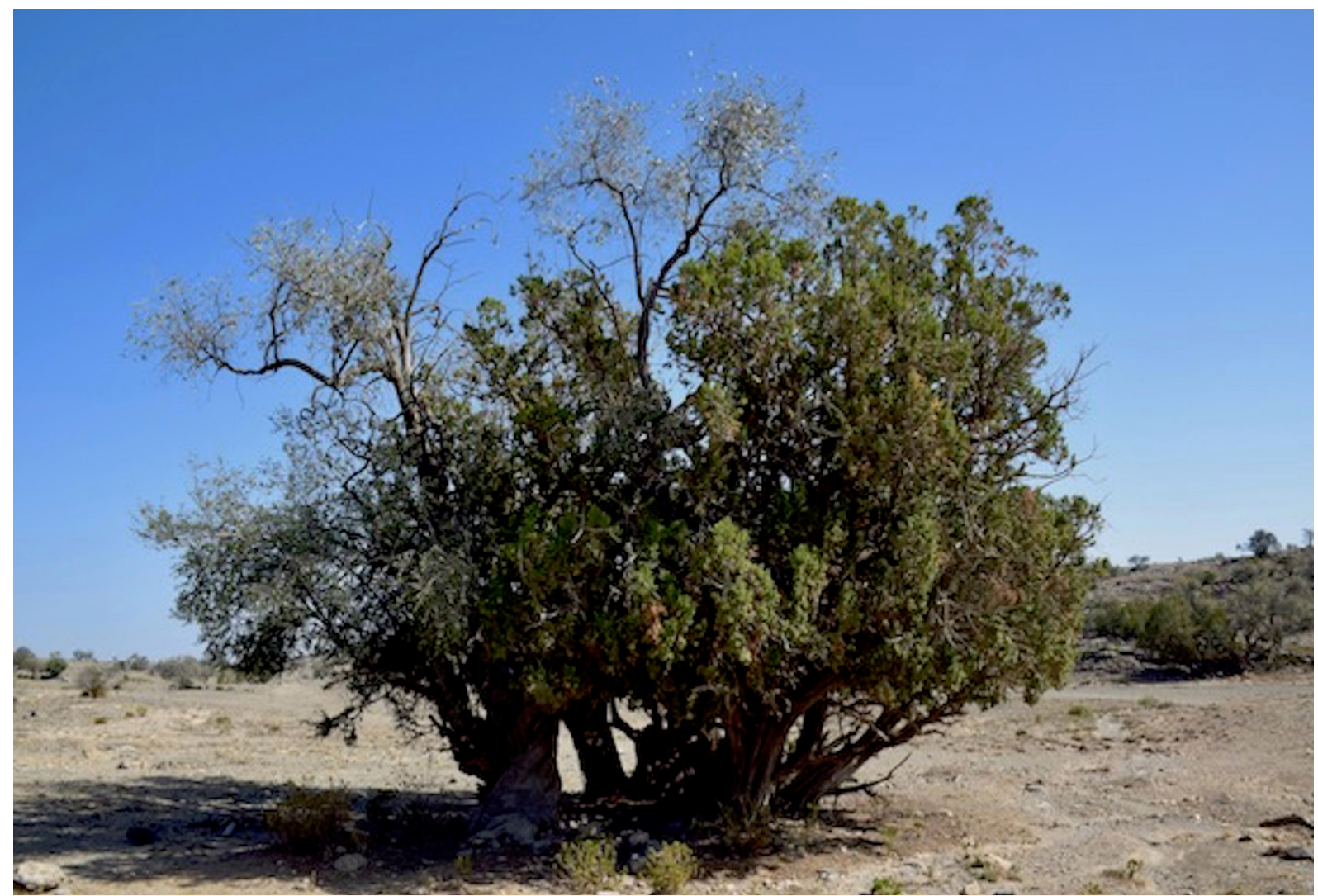

Figure 1. Juniperus seravschanica, Olea europaea, and Sideroxylon mascatense growing together in a cluster on Jebel Akhdhar, Oman (altitude $2340 \mathrm{~m}$ )

nursery transplants struggle to survive. It was further argued that temperatures and water availability could be the cause of the demise of J. seravschanica in their plant communities. The yields of the temperate fruit crops grown in the mountain oases have also decreased, possibly due to two major factors influencing agriculture in these mountainous areas: temperatures, i.e., chilling hours required for fruiting, and available water from irrigation or precipitation. Luedeling et al. (2009) found that between 1983 and 2008 there was an average decrease in chilling hours of 1.2-9.5 h/year. Using this data, they projected into the future with two different modelling scenarios; one predicted $13 \%$ and the other $75 \%$ of the years would have insufficient chilling hours for the production of pomegranate, the major tree fruit crop produced in the mountains (Luedeling et al., 2009). Thirty years of data from the Saiq meteorological station on Jebel Akhdhar, Oman, has shown an increase of minimum and mean temperatures, $+0.79^{\circ} \mathrm{C}$ per decade and $+0.27^{\circ} \mathrm{C}$ per decade respectively, with a decrease in precipitation of $-9.42 \mathrm{~mm}$ per decade (Al-Kalbani et al., 2015). Similarly, Luedeling and Buerkert (2008) found that by 2005 , there was already an imbalance in water resources in Jebel Akhdhar with demands exceeding supply. They went further to project that this imbalance would be exacerbated in the future with ever expanding urban development projects that compete with ag- riculture for the limited water resources (Luedeling and Buerkert, 2008b). Al-Kalbani et al. (2016) also confirmed this intense competition for water in their 2016 study. They discussed that even with the integration of desalinated water infrastructure, water management practices would need to improve in order to continue to supply water to agriculture as well as the other industries present (Al-Kalbani et al., 2016). The predominant irrigation method employed in the mountain oasis farms of Jebel Akhdhar is flood irrigation sourced from either afalaj networks or direct pumping from aquifers. Changing to more efficient irrigation methods that accurately disperse water to exactly where it is needed would greatly improve the water management practices for agriculture.

As stated earlier, in order to combat the effects of climate change, agricultural systems need to adapt (Howden et al., 2007). A possible adaptation strategy that agricultural systems could embrace would be selecting new crops that could thrive in the changing ecosystems. In the Western Hajar Mountains this could mean a reduction in the cultivation of temperate fruit crops and an increase in cultivation of crops that can tolerate higher temperatures and consume less water. Native plants and underutilized crops could be an alternative to extensive breeding projects and genetically modified crops. Sideroxylon mascatense, a plant native to Oman 


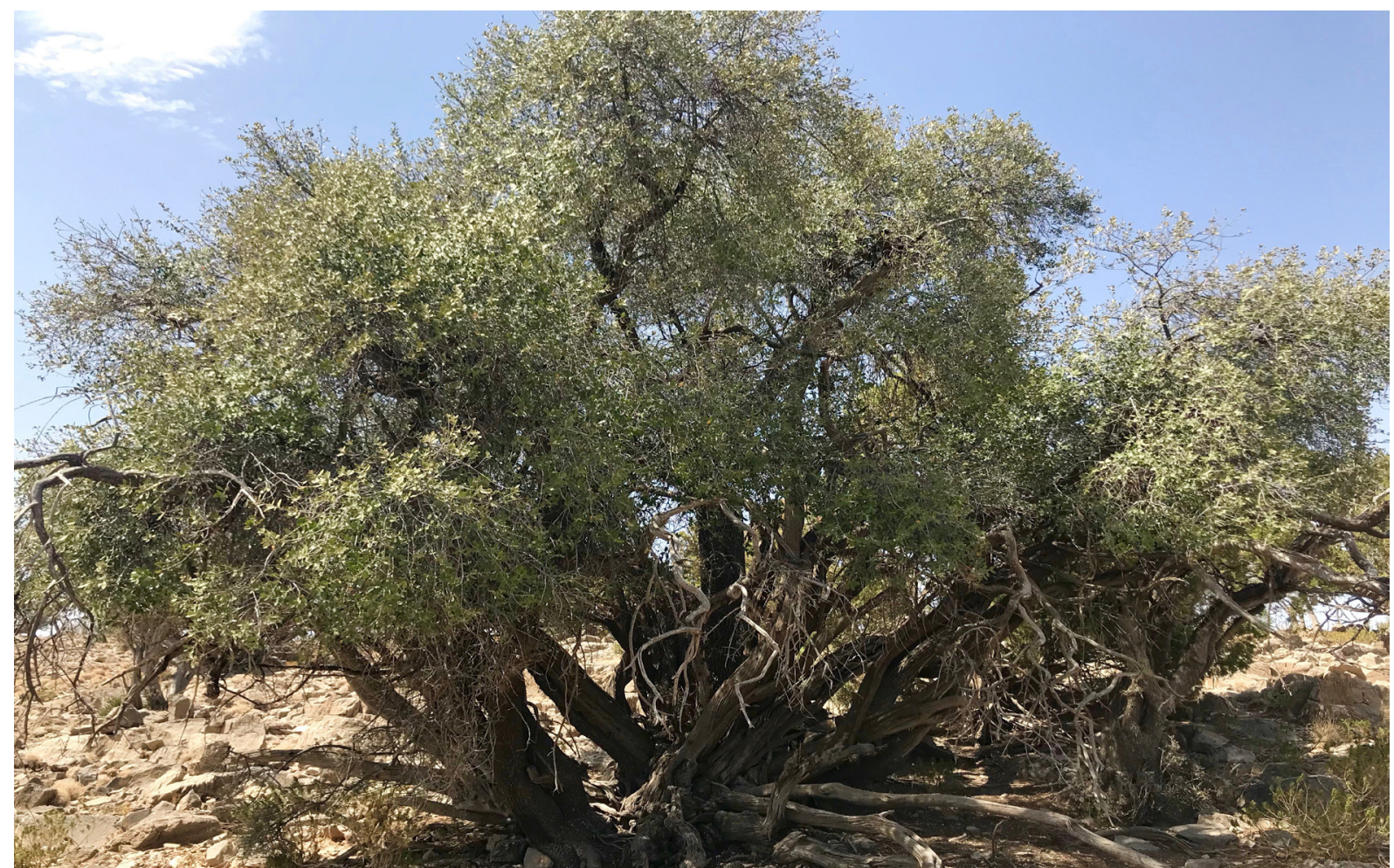

Figure 2. A large specimen of S. mascatense on Jebel Akhdhar, Oman (altitude 2313 m)

is one of many such plants (Ghazanfar, 2018). While not cultivated, S. mascatense is also native to Pakistan, Afghanistan, Iran, Yemen, Saudi Arabia, Somalia, and Ethi- opia (Al-Yahyai and Al-Nabhani, 2008; Swenson and Anderson, 2005; Thulin, 1993; Ullah et al., 2016; Van Breugel et al., 2016).

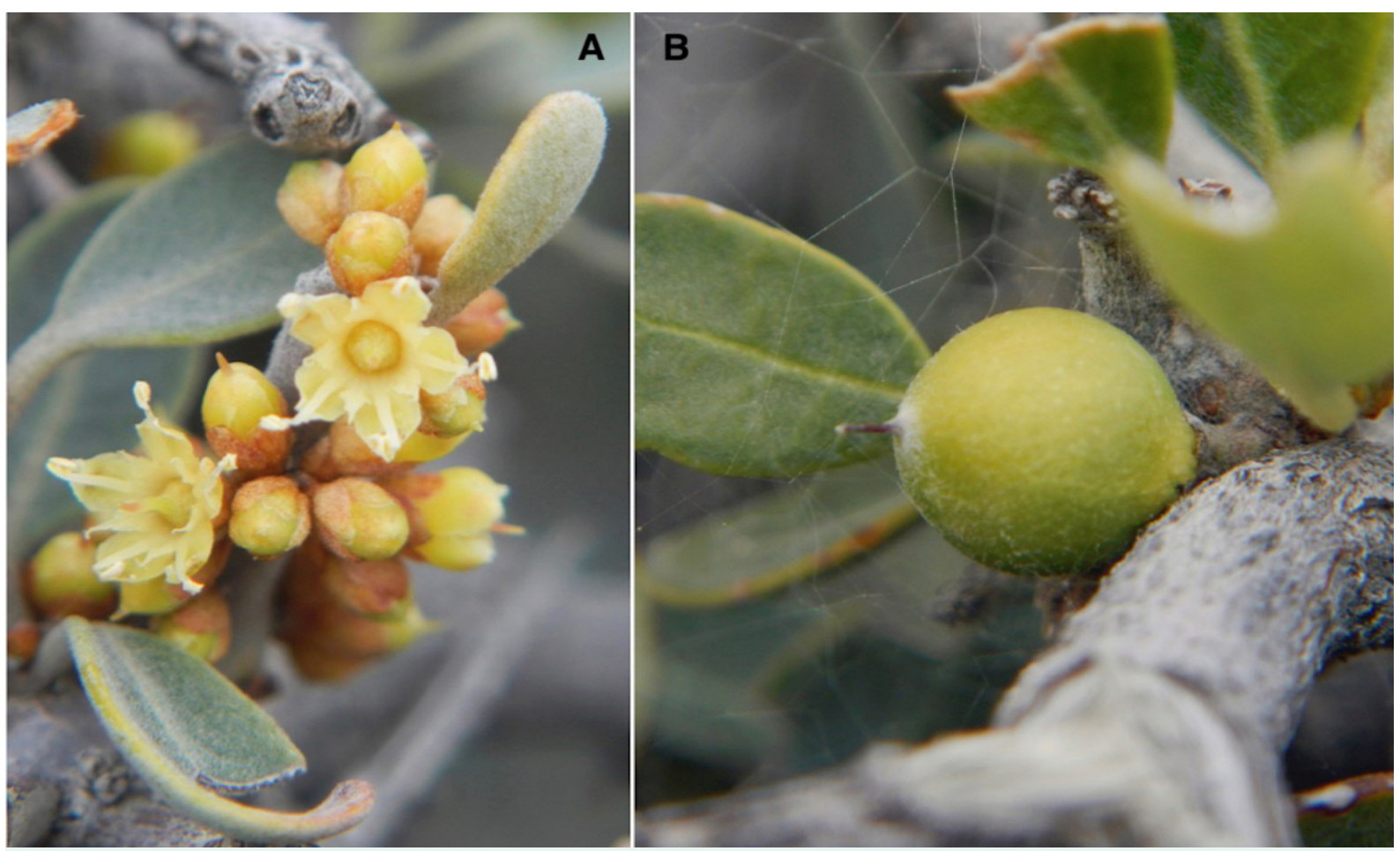

Figure 3. A. Flowers of S. mascatense, freshly opened, and unopened floral buds. B. Newly formed fruit of S. mascatense 


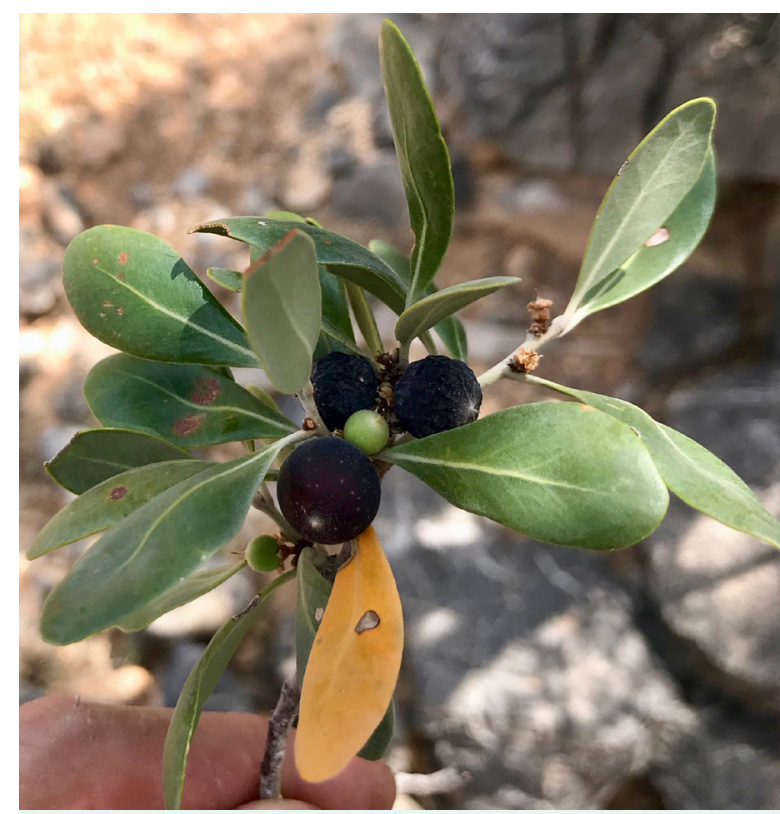

Figure 4. Purple fruiting variety of $S$. mascatense, known locally as 'Būt'

\section{Sideroxylon mascatense: Description and Habi- tat}

Sideroxylon mascatense, also known as Monotheca buxifolia, belongs to the family Sapotacea (Ghazanfar, 2003; Al-Yahyai and Al-Nabhani, 2008). S. mascatense is a key species in the higher elevation plant communities found in the Western Hajar Mountains of Oman, associated with Juniperus seravschanica, Olea europaea, Dodonaea viscosa, and Ziziphus hajarensis (Brinkmann et al., 2011; Ghazanfar, 2003; Patzelt, 2015b) as shown in Figure 1. It is also known to exist in the mountains of Dhofar in southern Oman (El-Sheikh, 2013; Ghazanfar, 2003). In Oman, S. mascatense grows throughout the mountains with the largest populations found at elevations from 1400 to 2400 meters (Al-Yahyai and Al-Nabhani, 2008). An evergreen plant, growing to height up to 4 meters, it can be classified as a large shrub or small tree (Al-Yahyai and Al-Nabhani, 2008; Ghazanfar, 2003; Patzelt, 2015a) (Figure 2). Flowers develop on new growth that occurs from January to April, with fruit maturing from April to September, depending upon elevation (Al-Yahyai and Al-Nabhani, 2008; Ghazanfar, 2003; Patzelt, 2015a) as shown in Figure 3. Ghazanfar (2003) described the existence of two different variants of the species in Oman. The most common, known locally as 'Būt' (pronounced "boot"), is a small purple fruit that is collected from the wild and small local gardens (Figure 4). The other variant is called 'Hegimt'; its yellow-brown-golden fruits are more sought after for their flavor (Ghazanfar, 2003) (Figure 5). While the size of the fruit varies greatly, in some instances it can reach $15 \mathrm{~mm}$ in diameter as shown in Figure 6. The fruit of this species can be found, when available and collected from the wild, in the

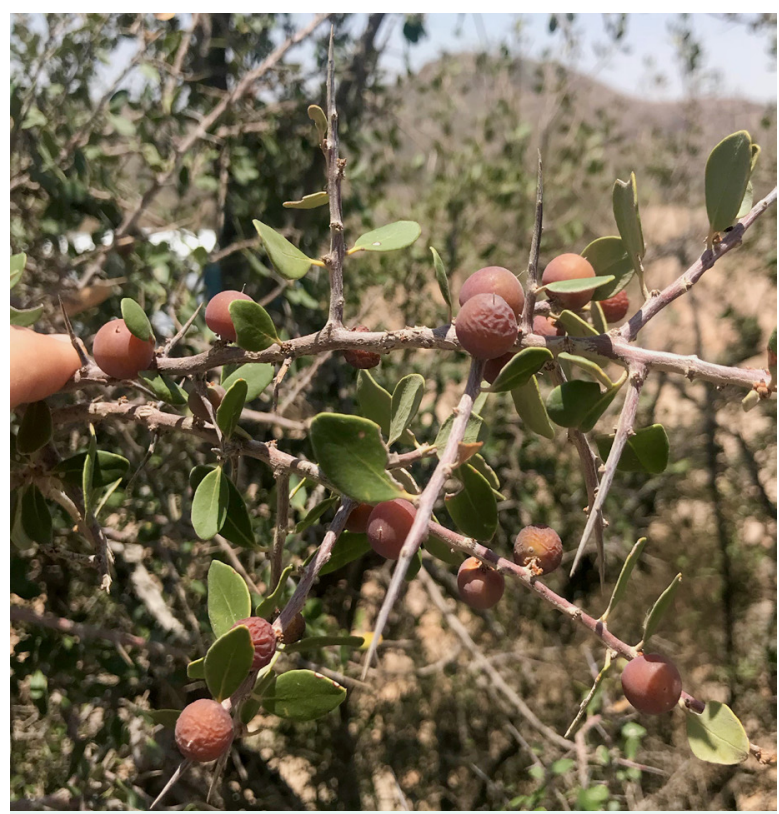

Figure 5. Yellow-brown-golden fruiting variety of $\mathrm{S}$. mascatense known locally as 'Hegimt'

small local markets (Gebauer et al., 2007). The seeds of $\mathrm{S}$. mascatense have a hard, dense seed coat (Al-Yahyai and Al-Nabhani, 2008). Huma et al. (2013) found that the best way to break dormancy to get germination of $S$. mascatense seeds was through mechanical scarification. Similarly, UI Haq et al. (2019) had success utilizing the fungus Rhizophus stolonifera to digest the seed coat to promote germination. They also succeeded in propagating S. mascatense through tissue culture (UI Haq et al., 2019).

\section{Existing and Potential Uses and Benefits}

Sideroxylon mascatense is typically wild harvested, although some specimens can be found in cultivated garden/farm settings. Known for its sweet taste, $\mathrm{S}$. mascatense fruit is consumed fresh when in season, but occasionally consumed dry as well. The lighter colored fruiting type, 'Hegimt', is known to have a lower Total Soluble Solid (TSS) content than the darker fruiting type, 'Būt' (Al-Yahyai and Al-Nabhani, 2008). Fruit of S. mascatense has also been shown to be a good source of antioxidants (Jan et al., 2013). More studies are needed to further describe all the nutritional benefits of both fruiting varieties of $\mathrm{S}$. mascatense.

Along with many nutritional qualities, $S$. mascatense fruit has been found to have medicinal benefits as well. Ghazanfar (2018) states that locals in Oman consume S. mascatense fruit as a "general health tonic" (pg. 212). In Pakistan, S. mascatense fruit has been consumed traditionally to treat a variety of intestinal issues as well as urinary tract infections (Murad et al., 2013; Aziz et al., 2018). The fruit is also consumed to improve digestion (Ullah et al., 2018). Extracts of the fruit were found to relieve pain, and reduce inflammation in mice (Ullah et 


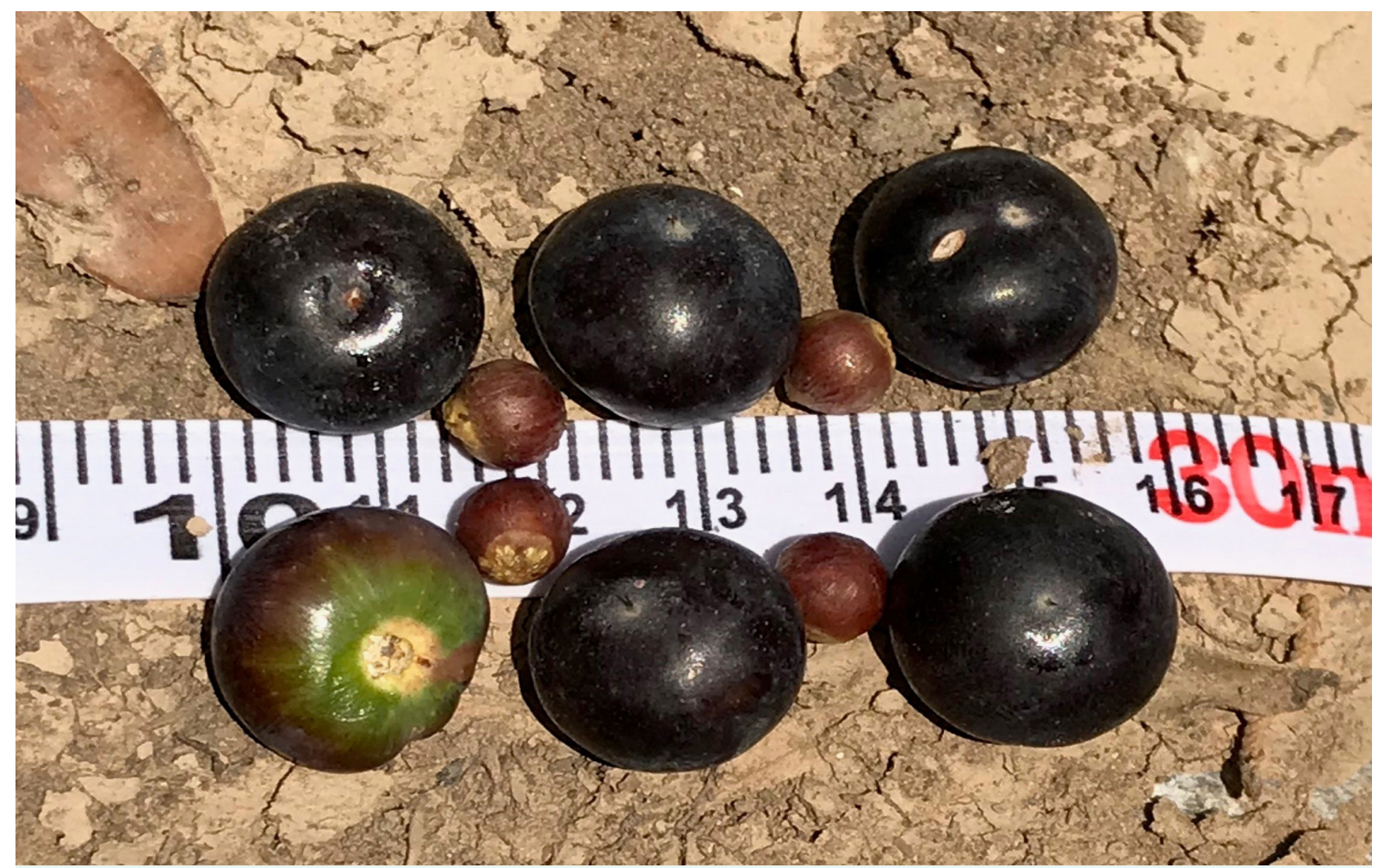

Figure 6. Large specimen of 'Būt'

al., 2016). Jan and Khan (2016) found S. mascatense fruit methanol extracts had possible repairing and restorative effects on kidney toxicity due to their antioxidant potential. Fruit of S. mascatense was also found to have some antibacterial properties (Ullah et al., 2017). Methanolic extracts from aerial portions of $\mathrm{S}$. mascatense were found to reduce pain, fever, and inflammation (Hassan et al., 2019). Burki et al. (2018) found that extracts of S. mascatense bark had anti-inflammatory and antidepressant properties. In Pakistan, leaves of S. mascatense have been fed to cows to correct abnormal milk flavors (Ul-Hassan et al., 2014).

\section{Conclusion}

In conclusion, whether wild harvested or cultivated, S. mascatense has been shown to be a valuable resource. With more research into nutritional and medicinal properties of the plant, it could prove to be the next super-fruit or supplement in the health food market. Additional research on value-added products could also make the commercial production of $\mathrm{S}$. mascatense more viable and profitable. Since $\mathrm{S}$. mascatense is still rarely seen in the commercial farm setting, research is also needed into the proper cultivation methods for an efficient yield and quality of the end product. Climate change is becoming a challenge to agriculture and threatening popularly utilized plant species. Therefore, focus could be shifted to underutilized plants native to areas affected most by climate change. This could allow sensitive areas to continue to have thriving agrarian systems.

\section{References}

Al-Farsi K, Lupton D, Hitchmough JD, Cameron RWF. (2017). How fast can conifers climb mountains? Investigating the effects of a changing climate on the viability of Juniperus seravschanica within the mountains of Oman, and developing a conservation strategy for this tree species. Journal of Arid Environments 147: 40-53.

Al-Kalbani MS, John C, Martin F. (2015). Recent Trends in Temperature and Precipitation in Al Jabal Al Akhdar,Sultanate of Oman, and the Implications for Future Climate Change. Journal of Earth Science \& Climatic Change 6: 1-9.

Al-Kalbani MS, Price MF, O'Higgins T, Ahmed M, Abahussain A. (2016). Integrated environmental assessment to explore water resources management in $\mathrm{Al}$ Jabal Al Akhdar, Sultanate of Oman. Regional Environmental Change 16:1345-1361.

Al-Yahyai RA, Al-Nabhani HS. (2008). Botanical Description and Phenological Cycles of Monotheca buxifolia. Acta Horticulturae 769: 247-254.

Atangana A, Khasa D, Chang S, Degrande A. (2014). Tropical Agroforestry. Springer Science, Dordrecht.

Aziz MA, Adnan M, Khan AH, Shahat AA, Al-Said 
MS, Ullah R. (2018). Traditional uses of medicinal plants practiced by the indigenous communities at Mohmand Agency, FATA, Pakistan. Journal of Ethnobiology and Ethnomedicine 14: 1-16.

Brinkmann K, Patzelt A, Schlecht E, Buerkert A. (2011). Use of environmental predictors for vegetation mapping in semi-arid mountain rangelands and the determination of conservation hotspots. Applied Vegetation Science 14: 17-30.

Burki S, Mehjabeen, Burki ZG, Shah ZA, Imran M, Khan M. (2018). Phytochemical screening, antioxidant and in vivo neuropharmacological effect of Monotheca buxifolia (Falc.) barks extract. Pakistan Journal of Pharmaceutical Science 31: 1519-1528.

Dubey SK, Pandey A, Sangwan RS (2017). Current Developments in Biotechnology and Bioengineering: Foundations of Biotechnology and Bioengineering. Kumar DS, Ashok P, Sangwan RS, editors. Elsevier, Amsterdam, Netherlands.

El Chami D, Daccache A. (2015). Assessing sustainability of winter wheat production under climate change scenarios in a humid climate - An integrated modelling framework. Agricultural Systems 140: 19-25.

El-Sheikh MA. (2013). Population structure of woody plants in the arid cloud forests of Dhofar, southern Oman. Acta Botanica Croatica 72: 97-111.

Gebauer J, Patzelt A, Hammer K, Buerkert A. (2007). First record of Grewia tenax (Forssk.) Fiori in northern Oman, a valuable fruit producing shrub. Genetic Resources and Crop Evolution 54: 1153-1158.

Ghazanfar SA. (2003). Flora of Oman Vol. 1. National Botanic Garden of Belgium, Meise.

Ghazanfar SA. (2018). Edible Wild Plants : A Case Study from Oman. In: Ozturk M, Hakeem KR, Ashraf $M$ Ahmad MSA, editors. Global Perspectives on Underutilized Crops. Springer International Publishing, Cham, Switzerland, p. 207-216.

Hassan S, Ahmad B, Khan SU, Linfang H, Anjum SI, Ansari MJ, Rahman K, Ahmad I, Khan WU, Qamar R, Man S, , Nabi G, Shah AH. (2019). In vivo pharmacological investigation of Monotheca buxifolia and Bosea amherstiana using animal models. Saudi Journal of Biological Sciences 26: 1602-1606.

Hopkins E, Al-Yahyai R. (2015). Landscaping with native plants in Oman. Acta Horticulturae 1097:181-192.

Howden SM, Soussana J-F, Tubiello FN, Chhetri N, Dunlop M, Meinke H. (2007). Adapting agriculture to climate change. Proceedings of the National Academy of Sciences 104: 19691-19696.

Huma Z, Rashid A, Ibrar M, Barkatullah, Hameed I. (2013). Effects of Chemical and Mechanical Scarification Treatments on Germination Rate of Monotheca buxifolia ( Flac ) Seeds. Pakhtunkhwa Journal of Life Science 1: 17-27.
Jan S, Khan MR. (2016). Protective effects of Monotheca buxifolia fruit on renal toxicity induced by $\mathrm{CCl} 4$ in rats. BMC Complementary and Alternative Medicine 16: 1-15 (e 289).

Jan S, Khan MR, Rashid U, Bokhari J. (2013). Assessment of Antioxidant Potential, Total Phenolics and Flavonoids of Different Solvent Fractions of Monotheca Buxifolia Fruit. Osong Public Health and Research Perspectives 4: 246-254.

Luedeling E, Buerkert A. (2008a). Typology of oases in northern Oman based on Landsat and SRTM imagery and geological survey data. Remote Sensing of Environment 112: 1181-1195.

Luedeling E, Buerkert A. (2008b). Effects of land use changes on the hydrological sustainability of mountain oases in northern Oman. Plant and Soil 304: $1-20$.

Luedeling E, Gebauer J, Buerkert A. (2009). Climate change effects on winter chill for tree crops with chilling requirements on the Arabian Peninsula. Climatic Change 96: 219-237.

MacLaren CA. (2016). Climate change drives decline of Juniperus seravschanica in Oman. Journal of Arid Environments 128: 91-100.

Murad W, Azizullah A, Adnan M, Tariq A, Khan KU, Waheed S, Ahmad A. (2013). Ethnobotanical assessment of plant resources of Banda Daud Shah, District Karak, Pakistan. Journal of Ethnobiology and Ethnomedicine 9: 1-10 (Article 77).

Patzelt A. (2015a). Synopsis of the Flora and Vegetation of Oman, with Special Emphasis on Patterns of Plant Endemism. Braunschweig, Cramer, Germany.

Patzelt A. (2015b). Photographic Field Guide to the Plants of the Western Hajar Mountains, Sultanate of Oman. Sultan Qaboos University Press, Muscat, Oman.

Swenson U, Anderson AA. (2005). Phylogeny, character evolution, and classification of Sapotaceae (Ericales). Cladistics 21: 101-130.

Thulin M, Royal Botanic Gardens K. (1993). Flora of Somalia Volume 3. Royal Botanical Gardens, Kew.

Ul Haq Z ul, Rashid A, Khan SM, Razzaq A, Al-Yahyai RA, Kamran S, Ali SG, Ali S, Saifullah, Abdullah, Rehman A. (2019). In vitro and in vivo propagation of Monotheca buxifolia (Falc.) A. DC. An economical medicinal plant. Acta Ecologica Sinica 39(6): 425430.

Ul Hassan H, Murad W, Tariq A, Ahmad A. (2014). Ethnoveterinary study of medicinal plants in Malakand Valley, District Dir (Lower), Khyber Pakhtunkhwa, Pakistan. Irish Veterinary Journal 67: 1-6.

Ullah A, Qureshi R, Iqbal Z, Rahman IU, Ali N, Shah M, Afzal A, ljaz F, Ullah S, Raza A, Ahmad M. (2018). 
Ethnomedicinal flora of Frontier Region Tank, Fata, Pakistan. Acta Ecologica Sinica 39(4): 321-327.

Ullah I, Khan JA, Iqbal Z, Hannan PA, Nasir F, Muhammad S, Jahan S, Rehman M. (2017). Chemical Composition, Anti-bacterial and Cytotoxic Potential of $\mathrm{n}$-Hexane Soluble Fraction of Monotheca buxifolia (Falc) A. DC. Fruit. National Academy Science Letters 40: 405-408.

Ullah I, Khan JA, Shahid M, Khan A, Adhikari A, Hannan PA, Javed I, Shakeel F, Farooq U. (2016). Pharmacological screening of Monotheca buxifolia (Falc.) A. DC. for antinociceptive, anti-inflammatory and antipyretic activities. BMC Complementary and Alternative Medicine 16: 1-8 (Article 273).
Van Breugel P, Friis I, Demissew S. (2016). The transitional semi-evergreen bushland in Ethiopia: Characterization and mapping of its distribution using predictive modelling. Applied Vegetation Science 19: 355-367.

Zekri S, Mbaga M, Fouzai A, Al-Shaqsi S. (2011). Recreational value of an oasis in Oman. Environmental Management 48:81-88. 